\title{
An Analysis of the Potential of Manufacturing and Services Sectors as Drivers of Economic Growth and Development in Namibia
}

\author{
Ronald T. Chifamba ${ }^{1}$, Ojijo Odhiambo ${ }^{2}$ \\ ${ }^{1}$ Department of Economics, University of Namibia, Namibia \\ ${ }^{2}$ United Nations Development Programme, Namibia \\ Correspondence: Ojijo Odhiambo, United Nations Development Programme, Namibia
}

Received: April 16, 2015 Accepted: May 7, 2015 Online Published: August 19, 2015

doi:10.11114/bms.v1i2.1046 URL: http://dx.doi.org/10.11114/bms.v1i2.1046

\begin{abstract}
The purpose of this paper is to analyse the potential of the manufacturing and services sectors as drivers of economic growth in Namibia. The paper uses the intersectoral linkage analysis method to identify the industries with the greatest backward and forward linkages. The economy-wide impact of these industries is simulated further using a CGE model. The greatest backward linkages for manufacturing industries were found in meat processing, fish processing, grain milling, basic metals and construction. The greatest backward linkages for the tertiary industries were found in trade and repairs, hotels and restaurants, finance and insurance, and other private services. The greatest forward linkages for manufacturing industries were found in paper and printing, chemicals and rubber, fabricated metals and machinery, and electricity generation and distribution. The greatest forward linkages for tertiary industries were found in transport, communication, finance and insurance, and market real estate and business services. These, therefore, are the sectors that policies could target as they have greatest impact and could enable Namibia to achieve higher levels of growth. Further, simulation results are obtained from a CGE model by introducing direct exogenous increases in the output of the perceived key industries and examining the economy-wide feedback effects.
\end{abstract}

Keywords: input-output model, inter-industry linkage, multiplier analysis, computable general equilibrium

\section{Introduction}

Namibia's long term development goal is "a prosperous and industrialized Namibia, developed by her human resources, enjoying peace, harmony and political stability" (Government of the Republic of Namibia, 2004). The Vision 2030, as the long term development goal is popularly known, is a broad development objective which guides the country's policy formulation and planning processes. It is designed to promote the creation of a diversified, open market economy, with a resource-based industrial sector and commercial agriculture; and the promotion of competitiveness in the export sector. The Vision also aims to reduce inequalities in income, improve access to and control of productive resources, enhance access to basic social services, and ultimately, move the nation up the scale of human development to be ranked among the developed countries of the world by 2030 .

Namibia is classified as an upper middle income country with an estimated annual Gross National Income (GNI) per capita of 9185 United States Dollars (2011 PPP\$) (UNDP, 2014). However, with an estimated 29 percent of the population classified as 'poor' and a Gini coefficient of 0.6, Namibia remains one of the most unequal societies in the world in terms of income distribution. Although the country has registered impressive growth rates, averaging 5.3 percent over the 2005 to 2014 period, unemployment remains stubbornly high and is currently estimated at 28 percent of the total potential work force when the broad definition of unemployment is applied. ${ }^{1}$ In terms of human

\footnotetext{
${ }^{1}$ As opposed to the strict definition of unemployed population which consists of all persons (15 years and above) who are either actively seeking work or are available to work during the labour force survey reference period, usually the week preceding the interview. The broad definition of unemployment drops the requirement that the person actively looks for work since in many developing countries, such as Namibia, with limited work opportunities, potential workers may well give up after unsuccessful period of looking for work.
} 
development and wellbeing, Namibia is classified as a medium human development country with a Human Development Index (HDI) of 0.624 and is ranked 127th out of the 187 countries for which the HDI has been calculated. When the HDI is adjusted for inequality however, the figure drops dramatically to 0.352 , representing a 43.6 percent loss in HDI, further reinforcing the fact that inequality is a serious challenge for Namibia.

In order to achieve the long term development goal, and especially to move significantly up the scale of human development to be ranked among the developed countries of the world, ${ }^{2}$ the Vision document calls for, inter alia, changes in the structure of the economy through diversification of economic activities, expansion of markets and enhancement of capital efficiency. Within the Vision 2030 time horizon (2004 to 2030), as part of the structural transformation process, the economy is expected to have reduced dependence on agricultural and mining products and increased its share of manufacturing and services products in output and employment. A gradual shift of labour from low factor-productivity primary industry (agriculture and mining) to manufacturing and services, is envisaged, thereby increasing resource allocation and utilisation efficiency in higher value-added sectors. This transformation, it is argued, would occur through diversification of production and venturing into new markets.

The contribution of the manufacturing and services sectors to gross domestic product (GDP) is expected to gradually rise from the 2008 figure of 75 percent to over 80 percent by 2030, with most of the increase being attributed to the development of the manufacturing sector. Through structural transformation of the economy, Namibia aims to reduce both her heavy reliance on natural resource extraction for export, as well as her reliance on imports, mainly from South Africa, to meet demand for goods and services. This transformation is expected to promote higher economic growth; create of decent and durable jobs; reduce poverty and inequality of income distribution; and bring about a general improvement in the welfare of the Namibian people. While the need for structural transformation is widely recognised and acknowledged in various policy documents, no attempt has been made to analyse the potential of the manufacturing and services industries to achieve the stated national development goal and objectives. This study seeks to estimate, empirically, the potential of the manufacturing and services industries in promotion of economic growth, employment creation and poverty reduction in Namibia. In particular, it seeks to determine the industries within the manufacturing and services sectors which, ceteris paribus, have the greatest potential to increase the growth rate of the economy and thus deserve increased public investment and policy support.

The potential of both the manufacturing and services sectors in achieving Namibia's long term development goal and objectives depends crucially on how these sectors are interlinked with the rest of the economy. An examination of such linkages is useful for purposes of formulating appropriate policies that might help to transform the structure of the economy. In this paper, the interlinkages are examined using the linkage analysis method to identify the industries with the greatest backward and forward linkages. The economy-wide impact of these industries is simulated using a Social Accounting Matrix (SAM)-based Computable General Equilibrium (CGE) model. The results from both the sectoral linkage analysis and the simulation exercise using the CGE model are then used to assess the potential of the manufacturing and service sectors.

The rest of the paper is structured as follows: Section 2 discusses, in greater detail, the structure of the Namibian economy, while a literature review and the analytical framework adopted are contained in Section 3. Section 4 presents the results of the analysis, and the conclusions and policy recommendations are presented in Section 5.

\section{Structure of the Namibian Economy}

\subsection{Economic Performance-Recent Trends}

The aggregate contribution of secondary and tertiary industries to Namibia's GDP has been on an upward trend in the recent past (Table 1). Over the 2010 to 2014 period, the percentage contribution of the primary sector declined from 17.6 to 14.0 percent, a trend which might suggest that the economy is moving in the right direction in terms structural transformation. However, the percentage contribution of the secondary sector also declined from 21.0 to 19.7 percent over the same period. These declines in the contribution of the primary and secondary sectors were compensated for by a rise in the contribution of the tertiary sector from 61.4 to 66.3 percent during this period, implying that labour has shifted from the primary industry to tertiary industry, by-passing secondary industry. Such a development not only

\footnotetext{
${ }^{2}$ A SAM for Namibia was constructed by Lange and Schade (2008) for the year 2004 as a revision of their earlier 2002 version. Their 2004 version was based on the 1993/94 National Household Income and Expenditure Survey (NHIES) as well as the national accounts and primary surveys.
} 
implies fragility of the transformation process, but is also likely to be unsustainable and runs counter to the stated long term development objective.

Table 1. Industry percentage contribution to GDP

\begin{tabular}{ccccc}
\hline Year & Primary & Secondary & Tertiary & $\begin{array}{c}\text { GDP at market prices } \\
\text { \$ million } \\
\text { Constant 2010 prices }\end{array}$ \\
\hline 2010 & 17.6 & 21.0 & & 19543 \\
2012 & 15.8 & 18.8 & 61.4 & 24181 \\
2014 & 14.0 & 19.7 & 65.4 & 23626 \\
\hline
\end{tabular}

Source: Constructed using data from Namibia Statistical Agency (2014)

\subsection{Sectoral Contribution to Growth}

Table 2 shows that the percentage contributions to GDP by the manufacturing industries, within the secondary industries, declined from 13.7 percent in 2011 to 11.8 percent in 2013. Thus the changes in the contribution of tertiary industry are largely driven by a wide fluctuation in the contribution of mining and quarrying which shifted between 9.9 percent and 14.5 percent of GDP over the 2008 to 2013 period. The low contribution of mining and quarrying in 2009 was due to the global financial crisis as well as other emerging global challenges. The global financial crisis reduced the demand for exports, specifically diamonds, demonstrating the negative effects of heavy reliance on volatile natural resource revenues.

Table 2. Annual contribution to GDP by the major industries

\begin{tabular}{cccccc}
\hline Year & $\begin{array}{c}\text { Mining and } \\
\text { quarrying }\end{array}$ & Manufacturing & $\begin{array}{c}\text { Wholesale and } \\
\text { retail trade }\end{array}$ & $\begin{array}{c}\text { Hotels and } \\
\text { restaurants }\end{array}$ & $\begin{array}{c}\text { Public } \\
\text { administration }\end{array}$ \\
\hline 2008 & 14.5 & 13.2 & 11.0 & 1.8 & 11.8 \\
2009 & 9.9 & 13.5 & 12.2 & 1.9 & 12.5 \\
2010 & 11.4 & 13.6 & 12.3 & 1.9 & 12.0 \\
2011 & 10.2 & 13.7 & 12.4 & 2.0 & 12.1 \\
2012 & 12.2 & 12.2 & 12.3 & 2.0 & 11.9 \\
2013 & 11.7 & 11.8 & 13.4 & 2.0 & 12.3 \\
\hline
\end{tabular}

Source: Constructed using data from Namibia Statistical Agency (2014)

Apart from the global level challenges cited above, the share contribution of industry to growth is a function of the relative growth rates of the different industries which also depend critically on their productive capacities. Therefore, facilitating the growth of industry may require policy interventions to change the structure of the economy through increased capital investment in the manufacturing and services industries.

There has been an improvement in the five-year annual average growth rates for primary and tertiary industry, while the secondary sector suffered a decline from 10.8 percent to 9.6 percent, a development which has a negative effect on the possibility of achieving the nation's long term development objective (Table 3). The 2010 to 2014 annual average growth rate of the primary sector increased by 4.7 percentage points from a negative growth rate of 2.9 percent to a positive growth of 1.8 percent, while the tertiary sector average growth improved from 5.4 percent to 6.7 percent over the same period. 
Figure 1 shows that, over the 1980 to 2012 period, compared to the other sectors, the growth rate of the primary sector exhibited wide fluctuations. This is indicative of the negative effects of dependence on the primary industries and points to the importance of moving from these industries to either secondary or tertiary industries which have fluctuated less. The growth rate of the tertiary sector has been steadier than that of the manufacturing sector.

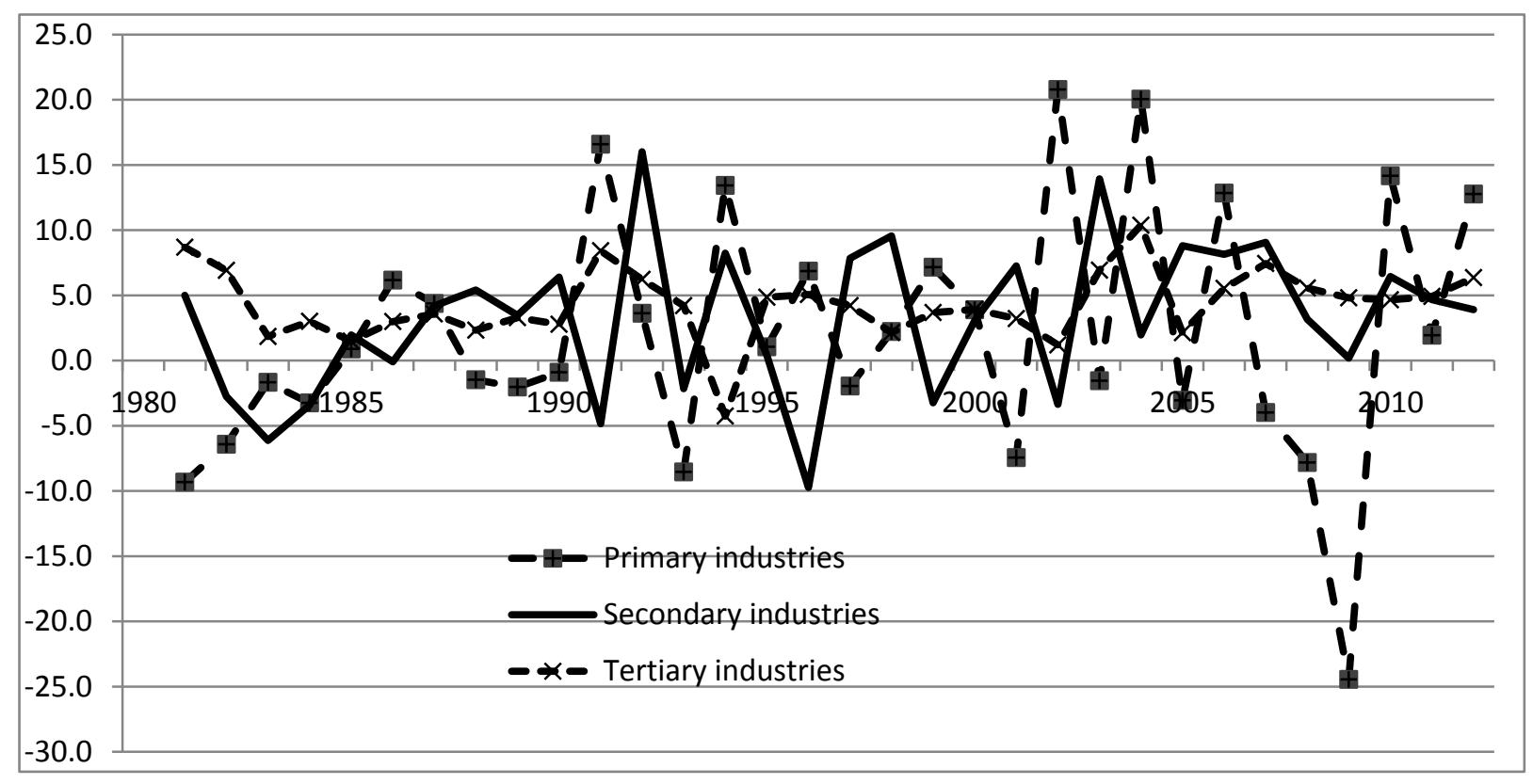

Figure 1. Industry growth rate (annual average percentage 1980-2012)

Table 3. Gross domestic expenditure and percentage contribution by consumption and gross fixed capital formation (5 year average)

\begin{tabular}{lcc}
\hline & $2004-2008$ & $2009-2013$ \\
\hline Gross national expenditure (Billion Namibian dollars) & 69.7 & 104.2 \\
Final consumption expenditure, etc. (\% of expenditure) & 80.5 & 78.0 \\
Gross fixed capital formation (\% of expenditure) & 19.5 & 22.0 \\
\hline
\end{tabular}

Source: Constructed using data from Namibia Statistical Agency (2014)

Economic theory posits that different industries have different potential to create employment, that is, rapid growth in some sectors or industries does not always translate into commensurate employment creation.

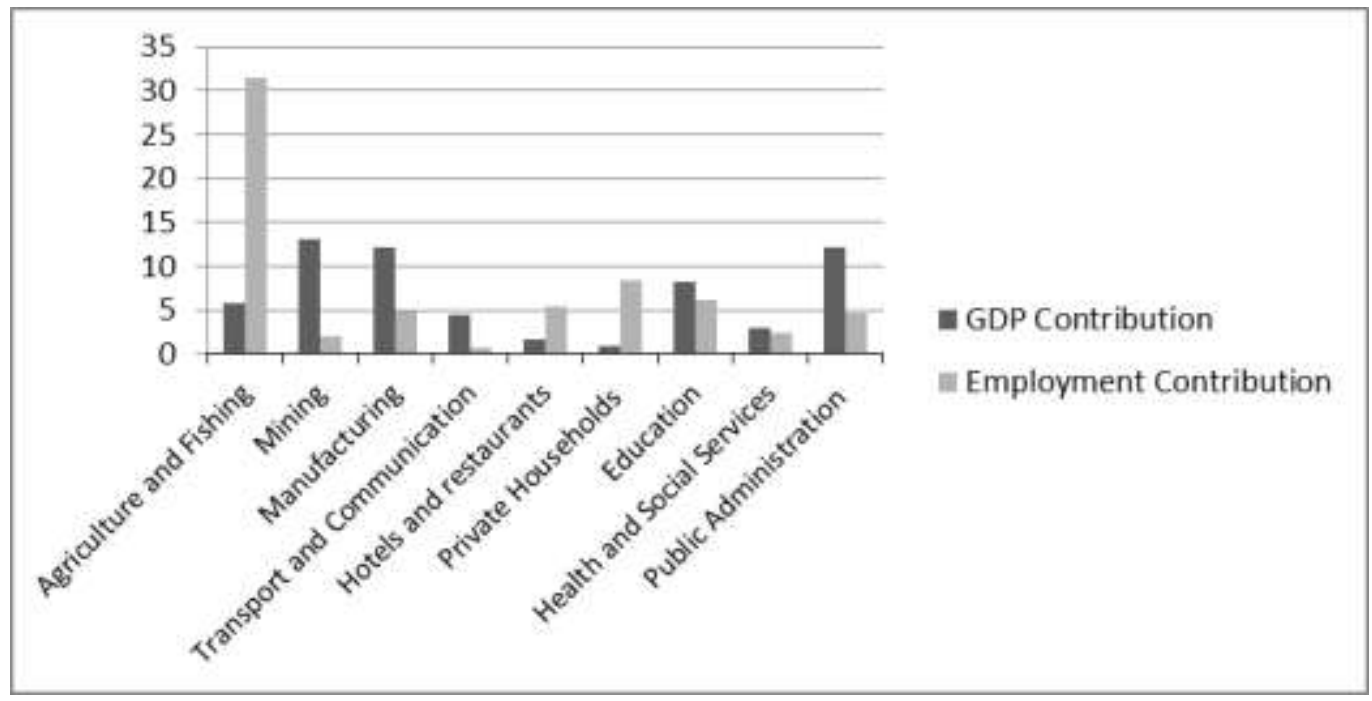

Figure 2. GDP and Employment Contribution of selected sectors, 2013 
Source: Constructed using data from 2013 Annual National Accounts and Labour Force Survey

The high unemployment rate and poverty levels of 28 percent and 29 percent, call for supportive measures to improve the growth rates of industries with the potential to absorb the unemployed labour force. In order to find ways to create sustainable jobs, the Bank of Namibia undertook a research study in 2009 from which they recommended a targeted approach to economic development paying attention to economic sectors with the greatest potential to grow and create jobs, including transport, tourism and agriculture (BON, 2009).

\section{Methodology}

Different measures and methodological approaches have been proposed in the literature for identifying key sectors of an economy. Some of these estimation methodologies relate to backward and forward linkages and are based on the work by Chenery and Watanabe (1958), Rasmussen (1956) and Hirschman (1958). Surveys that introduce many of the relevant concepts and the development of intersectoral linkages in the literature include Dietzenbacher (2002). Some recent applications to find intersectoral linkages include Andreosso-O'Callaghan and Yue (2004) for China, Salami (2012) for Iran, Kowalewski (2013) for Germany, and Egilmez et al. (2013) for the USA.

\subsection{The Demand Driven Model}

In this study we use impact analysis to identify and quantify the economic impact of a given sector in the economy, in terms of its backward and forward linkages. We identify the industries with the greatest linkages within the economy using a partial sectoral linkage analysis. The analysis in this paper is partial in the sense that it calculates the linkage indices only for the industries in the Social Accounting Matrix (SAM), with the input-output coefficients based on the full SAM. ${ }^{3}$ An example of the estimation of the full set of coefficients is provided in Blancas (2006) in an application to the Mexican economy. These coefficients are analysed using the typical input-output methods that are based on the direct input coefficients.

In general, the direct and indirect short-run effects (impact effects) and multipliers are calculated using elements of the Leontief inverse, $(I-A)^{-1}$ derived from:

$$
\boldsymbol{X}=(\boldsymbol{I}-\boldsymbol{A})^{-\mathbf{1}} F
$$

where $X$ is industry output, $F$ is a vector of final demands and $A$ are the direct input (technical) coefficients (Leontief, 1936).

The elements of the Leontief inverse provide the multipliers that show the comparative static effects from changes in final demand. The column (row) sums of the Leontief inverse matrix were used to measure the intersectoral linkages so as to take into account both direct and indirect backward and forward linkage effects. Total backward and total forward linkage indicators are also called output multipliers and input multipliers, respectively (Drejer, 2002). Two normalised indices, the power of dispersion index, $D_{j}^{d P}$, and the sensitivity of dispersion index, $D_{j}^{d S}$, were used to capture the backward and forward linkages, respectively. The power of dispersion index describes the relative extent to which an increase in final demand for the products of a given industry is dispersed throughout the total system of industries. The sensitivity of dispersion index measures the increase in the production of a given industry driven by a unit increase in the final demand for all industries in the system.

We calculated the power and sensitivity of dispersion indices using the, respective, formulae

$$
D_{j}^{d P}=n \frac{\sum_{i} B_{i j}}{\sum_{i} \Sigma_{j} B_{i j}} \quad \text { and } \quad D_{i}^{d S}=n \frac{\sum_{j} B_{i j}}{\sum_{i} \Sigma_{j} B_{i j}}
$$

where $n$ is the number of industries, $\sum_{i} B_{i j}$ is the sum of the column elements in the Leontief inverse matrix, $B=(I-A)^{-1}$. The elements $B_{i j}=\partial X_{i} / \partial F_{j}$ represent the total direct and indirect outputs in sector $i$ per unit of the final demand in sector $j . \sum_{j} B_{i j}$ is the sum of the row elements in the Leontief inverse matrix and $\sum_{i} \sum_{j} B_{i j}$ is the sum of all the elements of the Leontief inverse. The weighting introduced by $\sum_{i} \sum_{j} B_{i j}$ normalises the linkage index, so that a value greater than unity shows that the industry supports the demand for the other industries by more than the average of all industries, that is, the industry generates a relatively large share of the increase of final demand for the products from other industries. Conversely, an industry with a linkage value below unity supports a low level of demand for products from other industries. The average linkage value is unity since the sum of the linkage values is always equal to the number of industries in the system. According to Cristobal and Brezma (2006), a key sector has both backward linkage and forward linkage values greater than unity.

\footnotetext{
${ }^{3}$ On average, very high human development countries, most of which are members of the Organisation for Economic Cooperation and Development (OECD), currently have an HDI of 0.89 .
} 


\subsection{The Supply Driven Model}

The demand driven model critically depends on the assumption of fixed input coefficients and a perfectly elastic supply of inputs in order to analyze the impact of final demand, or backward linkage, and output orientation of activities (Oosterhaven, 1988, 1996). In addition, the multipliers from the demand driven model are not always appropriate for measuring primary supply, or forward linkage, and the input orientation of activities. In that case the supply-driven model can be used (Davis and Salkin, 1984).

The supply driven counterpart to the demand driven model is specified as

$$
\boldsymbol{X}^{\prime}=\boldsymbol{V}^{\prime}(\boldsymbol{I}-\boldsymbol{R})^{-\mathbf{1}}
$$

where $V$ is the vector of Value Added from industry $j$ and $R$ are the direct ouput coefficients. A prime ( ' ) denotes the transpose of the given matrix. We calculated the backward linkage, $D_{i}^{P I}$, and forward linkage, $D_{j}^{S S}$, effects using the formulae

$$
D_{i}^{P I}=n \frac{\sum_{j} G_{i j}}{\sum_{i} \Sigma_{j} G_{i j}} \quad \text { and } \quad D_{j}^{S S}=n \frac{\sum_{i} G_{i j}}{\sum_{i} \Sigma_{j} G_{i j}}
$$

where $\sum_{j} G_{i j}$ is the sum of the row elements in the Ghosh inverse matrix $(I-R)^{-\mathbf{1}}$ (Ghosh, 1958). The elements $G_{i j}=\partial X_{j} / \partial F V_{i}$ represent the total direct and indirect requirements in sector $j$ per unit of the final value added in sector $i$.

\subsection{An Analysis of Exogenous Impacts}

After identifying the sectors with the greatest linkages, the economy-wide effect of exogenous changes in these industries was simulated using the Computable General Equilibrium (CGE) model. The model was used to simulate the actual changes that would be expected to occur in the economy given exogenously induced changes in the key sectors. This method of selection is suggested by Yeldan (1986).

The advantage of using the CGE framework is that it provides consistent accounting of the macroeconomic quantities, prices and welfare effects of policy changes as well as other exogenous ones. As a result, the standard CGE model has been applied extensively in both developed and developing countries to quantify the effects of macroeconomic policies on, inter alia, income distribution, trade decisions, development outcomes, environmental impact, public finance, long term growth and structural change.

\section{Results and Discussions}

In this section the results of the impact analysis, identifying and quantifying the economic impact of the various sectors of the Namibian economy, and the economy-wide effects of exogenous changes of these sectors are discussed. Table 4 shows the sectoral backward and forward indices for the demand driven model calculated using data from the 2004 Namibia SAM.

It is established that, in general, these linkages are greatest for the services industries. Only the service sectors - market real estate and business services ( 0.95 , rank 15) and Government Services (0.93, rank 16) - have backward linkages lower than unity while all the others have indices that are greater than unity. In terms of the overall index, transport (2.50, rank 3$)$, communication (2.22, rank 6), and finance and insurance (2.72, rank 2 ) all have both backward and forward linkages that are greater than unity. From the theoretical framework discussed in Section 3, these are the industries contributing the most to meeting demand while also providing high demand for the products of other industries. Backward linkage effects are greatest in the trade and repairs sector (1.97, rank 2), other government services (1.88, rank 4) and finance and insurance (1.51, rank 1.51). Forward linkage effects feature most prominently in market real estate and business services (2.19, rank 3), finance and insurance (1.84, rank 4) and transport (1.51, rank 5). 
Table 4. Sectoral backward and forward linkage effects (demand-driven)

\begin{tabular}{|c|c|c|c|c|c|c|}
\hline Industry & $\begin{array}{l}\text { Dispersion } \\
\text { index (1) }\end{array}$ & Rank & $\begin{array}{c}\text { Sensitivity } \\
\text { index (2) }\end{array}$ & Rank & $\begin{array}{c}\text { Overall } \\
\text { effect } \\
(1)+(2)\end{array}$ & Rank \\
\hline Commercial cereal crops & 0.76 & 26 & 0.98 & 12 & 1.74 & 22 \\
\hline Other commercial crops & 0.80 & 24 & 0.75 & 21 & 1.55 & 27 \\
\hline Commercial animal products & 0.89 & 18 & 1.02 & 10 & 1.91 & 15 \\
\hline Fishing & 0.91 & 17 & 0.96 & 13 & 1.88 & 19 \\
\hline Mining & 1.13 & 8 & 1.11 & 7 & 2.24 & 5 \\
\hline Meat processing & 1.21 & 4 & 0.73 & 24 & 1.93 & 12 \\
\hline Fish processing & 1.15 & 5 & 0.68 & 27 & 1.84 & 20 \\
\hline Grain milling & 1.08 & 10 & 0.81 & 18 & 1.89 & 17 \\
\hline Beverages and other food processing & 0.97 & 14 & 1.01 & 11 & 1.98 & 10 \\
\hline Textiles & 0.79 & 25 & 0.89 & 16 & 1.68 & 25 \\
\hline Wood and Furniture & 0.80 & 22 & 0.91 & 15 & 1.71 & 23 \\
\hline Paper and printing & 0.84 & 21 & 1.08 & 8 & 1.92 & 14 \\
\hline Chemicals and rubber & 0.80 & 23 & 1.38 & 4 & 2.18 & 7 \\
\hline Non-metallic mineral products & 0.88 & 20 & 0.82 & 17 & 1.70 & 24 \\
\hline Basic metals & 1.10 & 9 & 0.70 & 26 & 1.80 & 21 \\
\hline Fabricated metals and machinery & 0.73 & 27 & 1.62 & 2 & 2.34 & 4 \\
\hline Electricity & 0.88 & 19 & 1.04 & 9 & 1.92 & 13 \\
\hline Water & 1.05 & 11 & 0.92 & 14 & 1.97 & 11 \\
\hline Construction & 1.29 & 3 & 0.73 & 23 & 2.02 & 9 \\
\hline Trade and repairs & 1.35 & 2 & 0.78 & 19 & 2.13 & 8 \\
\hline Hotels and restaurants & 1.14 & 6 & 0.74 & 22 & 1.88 & 18 \\
\hline Transport & 1.05 & 12 & 1.45 & 3 & 2.50 & 3 \\
\hline Communication & 1.05 & 13 & 1.18 & 6 & 2.22 & 6 \\
\hline Finance and insurance & 1.36 & 1 & 1.36 & 5 & 2.72 & 2 \\
\hline \multicolumn{7}{|l|}{ Market real estate and business } \\
\hline services & 0.95 & 15 & 1.88 & 1 & 2.83 & 1 \\
\hline Other private services & 1.14 & 7 & 0.77 & 20 & 1.91 & 16 \\
\hline Government services & 0.93 & 16 & 0.70 & 25 & 1.63 & 26 \\
\hline Index Sum & 27 & & 27 & & 54 & \\
\hline
\end{tabular}

None of the manufacturing industries have both backward and forward linkage indices greater than unity. This implies that each of the manufacturing industries is either demand-driven or only creates demand for the other industries. Six of the fourteen manufacturing industries in the 2004 SAM have backward linkage indices that are greater than unity. In order of ranking these are: construction (1.29, rank 3), meat processing (1.21, rank 4), fish processing (1.15, rank 5), basic metals (1.10, rank 9), grain milling (1.08, rank 10) and water (1.05, rank 11). Five of the manufacturing industries have forward linkage indices greater than unity. These are: fabricated metals and machinery (1.62, rank 2), chemicals and rubber (1.38, rank 4), paper and printing (1.08, rank 8), electricity (1.04, rank 9), and beverages and other food products, (1.01, rank 11).

Backward and forward linkages from the supply-driven model have also been calculated in order to measure the primary supply and input orientation of activities (Table 5). These indices capture the backward linkage effects and the forward linkage effects. Only two of the manufacturing industries have backward linkage effects greater than unity. These are construction (1.91, rank 3), and beverages and other food production (1.42, rank 7). With the exception of hotels and restaurants, and communication, all the services industries have backward linkage effects that are greater than unity. Forward linkage effects are greatest in chemicals and rubber (3.86, rank 1) and fabricated metals and machinery (2.84, rank 2). The implantation of policies that support the identified industries would have the potential to increase the growth rate of the economy, provided that the structure of the economy remains the same. 
Table 5. Backward linkage and forward linkage effects (supply-driven model)

\begin{tabular}{|c|c|c|c|c|c|c|}
\hline Industry & $\begin{array}{c}\text { Backward } \\
\text { linkage } \\
\text { effect }\end{array}$ & Rank & $\begin{array}{l}\text { Forward } \\
\text { linkage } \\
\text { effect }\end{array}$ & Rank & Total & Rank \\
\hline Commercial cereal crops & 0.43 & 27 & 1.07 & 8 & 1.49 & 16 \\
\hline Other commercial crops & 0.49 & 25 & 0.57 & 16 & 1.06 & 26 \\
\hline Commercial animal products & 0.62 & 19 & 0.64 & 13 & 1.25 & 21 \\
\hline Fishing & 0.87 & 10 & 0.51 & 19 & 1.38 & 18 \\
\hline Mining & 2.45 & 1 & 0.56 & 17 & 3.01 & 5 \\
\hline Meat processing & 0.84 & 13 & 0.45 & 23 & 1.29 & 19 \\
\hline Fish processing & 0.72 & 18 & 0.41 & 27 & 1.13 & 24 \\
\hline Grain milling & 0.85 & 12 & 0.67 & 12 & 1.52 & 15 \\
\hline Beverages and other food processing & 1.42 & 7 & 0.54 & 18 & 1.96 & 12 \\
\hline Textiles & 0.53 & 22 & 0.58 & 15 & 1.10 & 25 \\
\hline Wood and Furniture & 0.52 & 23 & 0.96 & 9 & 1.48 & 17 \\
\hline Paper and printing & 0.53 & 21 & 1.47 & 6 & 2.00 & 11 \\
\hline Chemicals and rubber & 0.87 & 11 & 3.86 & 1 & 4.73 & 1 \\
\hline Non-metallic mineral products & 0.49 & 26 & 0.68 & 11 & 1.17 & 22 \\
\hline Basic metals & 0.74 & 17 & 0.41 & 26 & 1.15 & 23 \\
\hline Fabricated metals and machinery & 0.78 & 16 & 2.84 & 2 & 3.63 & 2 \\
\hline Electricity & 0.58 & 20 & 1.45 & 7 & 2.03 & 10 \\
\hline Water & 0.51 & 24 & 0.46 & 21 & 0.97 & 27 \\
\hline Construction & 1.91 & 3 & 0.51 & 20 & 2.41 & 8 \\
\hline Trade and repairs & 1.97 & 2 & 0.61 & 14 & 2.58 & 7 \\
\hline Hotels and restaurants & 0.82 & 15 & 0.45 & 22 & 1.27 & 20 \\
\hline Transport & 1.44 & 6 & 1.51 & 5 & 2.95 & 6 \\
\hline Communication & 0.83 & 14 & 0.90 & 10 & 1.74 & 13 \\
\hline Finance and insurance & 1.51 & 5 & 1.84 & 4 & 3.35 & 4 \\
\hline Market real estate and business services & 1.30 & 8 & 2.19 & 3 & 3.49 & 3 \\
\hline Other private services & 1.10 & 9 & 0.44 & 24 & 1.53 & 14 \\
\hline Government services & 1.88 & 4 & 0.42 & 25 & 2.30 & 9 \\
\hline
\end{tabular}

With respect to the economy-wide effects of exogenous changes, the greatest impact was found on beverages and other food processing, with a 12.22 percent increase. Other industries that showed increases in the value added are commercial cereal crops (3.90 percent), commercial animal products (4.66 percent), fishing (4.22 percent), chemicals and rubber (1.96 percent), non-metallic mineral products (1.32 percent), fabricated metals and machinery ( 3.87 percent), transport (2.04 percent), finance and insurance (1.37 percent), and market real estate and business services (2.43 percent). These results suggest that focusing on policies that promote these industries would have the greatest impact on the economy.

The CGE based simulation models assume that the basic structure of the economy remains the same (apart from structural changes that might be introduced via alternative elasticity values governing the substitution possibilities). In order to conduct the simulations, benchmark prices were all set equal to 1 for the exchange rate (price of foreign currency in local currency), the price received for exported product (excluding export taxes), price of local product (excluding all taxes on products), world price of imported product (expressed in foreign currency) and the wage rate for both skilled and unskilled labour. The initial responsiveness of parameters that depended on the price was set to 1 in order to check the homogeneity of the model. A homogeneity check was done by doubling prices one at a time. For wages and capital the result was halving of the demands for labour and capital in all the sectors.

The population growth rate used to control the growth rate in all the other variables was set at 3 percent. The interest rate in Namibia during the benchmark period was set at the prime lending rate of 12 percent, obtained from Bank of 
Namibia Reports (BON, 2008).

The results from simulations depend on the values assigned to the exogenous variables and parameters so that different specifications give different results. It is, therefore, important to test the sensitivity of the model to changes in the exogenous variables. Currently most of these tests are done in an ad hoc manner and are prone to subjective judgement. Abdelkhalek and Dufour (2006) suggest some bounds to use for testing but these have not been applied in this study. In order to resolve the problem to some extent, the first task was to examine the feasible ranges of transformation and substitution elasticities (CET and CES respectively) that conform to the Namibia 2004 SAM data. After establishing some rough bounds for these elasticities, further simulations were undertaken for the responsiveness of the economy to policy-induced and other exogenous shocks.

Since there are different sets of elasticities depending on the goods and factor aggregation, an assessment of the sensitivity of the results required a large number of combinations of the elasticities. Replication checks were done for different values of elasticities. Values of these were changed until the equilibrium values for the endogenous variables stabilised. On the basis of the calibration checks, the benchmark data for parameters used for the final analysis are as follows: price elasticity of indexed transfers and parameters (1.0); price elasticity of the world demand for exports of product (0.1); investment demand function (3.5); elasticities of composite capital (3.0), composite labour - mining (0.9); composite labour - agriculture (2.0); composite good (1.2); value added (1.2); export and local sales for all industries (0.9); total output (0.99); and world demand for exports (0.1). These were used to calibrate the scale, share and other elasticity parameters of the CET and CES.

The income elasticities of consumption were set at different values for products from different industries. Income elasticity for agricultural products was set at a low value of 0.7 . The value of 1.1 was set for products from mining, manufacturing and other secondary industries. Services in general as well as those from the government were assigned values of 1.05. The Frisch parameter for the LES function was set at -1.515 .

The Namibia SAM contains trade margins between production and consumption, which represent transportation costs or mark-ups for wholesale and retail shops. These margins are paid by some industries to some of the service industries. The figures for the margins were distributed between import and domestic supply in their respective proportion to total supply. The remainder was distributed between domestic demand and exports using their relative contributions to total demand.

Simulation results in this study were obtained when direct exogenous increases in the output of the key industries are introduced in the model while inputs remain fixed. A similar CGE based simulation has been carried out for the agricultural sector in Western Australia by Ahammad (2002). The simulation results reported are based on a 10 percent increase in the output of meat processing, fish processing, grain milling, basic metals, and construction. These industries will have marginal changes in value added since they are the ones used for control purposes and the slight changes reflect the feedback effects from changes in the remaining industries (Table 6).

The results from the simulation clearly show that, given the current structure of the Namibian economy and providing this structure remains the same, there will be no greater potential of the manufacturing and services industries over the remaining sectors. This obvious but important result suggests that the most plausible way in which higher value addition can be obtained from the manufacturing and services industries is through increased investment in these industries relative to the other industries. Therefore, the possibility of unlocking the potential of the economy and achieving structural transformation is to have increased investment in those industries that have both backward and forward linkages that are greater than unity (key sectors) relative to the remaining ones. These industries are transport, communication, and finance and insurance. Although none of the manufacturing industries has both backward and forward linkages indices greater than unity, almost half of the manufacturing industries have backward linkages greater than unity, implying that these industries support the demand for other industries by more than the average of all industries or, simply put, generate a relatively large share of the increase of the final demand for products from other industries. Those with strong backward linkages are construction, meat processing, fish processing, basic metals, grain milling, and water. 
Table 6. Original and simulated percentage changes in value added for industries

\begin{tabular}{|c|c|c|}
\hline Industry & Original & Simulated percentage change \\
\hline Commercial cereal crops & 88 & 3.90 \\
\hline Other commercial crops & 317 & 0.21 \\
\hline Commercial animal products & 887 & 4.66 \\
\hline Fishing & 3483.5 & 4.22 \\
\hline Mining & 9713.5 & 0.55 \\
\hline Meat processing & 362.1 & 10.02 \\
\hline Fish processing & 2195.0 & 10.04 \\
\hline Grain milling & 1078.0 & 10.95 \\
\hline Beverages and other food processing & 3314.4 & 12.22 \\
\hline Textiles & 1860.5 & 0.49 \\
\hline Wood and Furniture & 443.6 & 0.48 \\
\hline Paper and printing & 197.4 & 0.97 \\
\hline Chemicals and rubber & 771.2 & 1.96 \\
\hline Non-metallic mineral products & 390.2 & 1.32 \\
\hline Basic metals & 982.5 & 0.28 \\
\hline Fabricated metals and machinery & 736.3 & 3.87 \\
\hline Electricity & 2323.3 & 0.55 \\
\hline Water & 1320.7 & 0.24 \\
\hline Construction & 3493.0 & 10.05 \\
\hline Trade and repairs & 10542.5 & 0.21 \\
\hline Hotels and restaurants & 1916.4 & 0.09 \\
\hline Transport & 3823.7 & 2.04 \\
\hline Communication & 3539.4 & 0.70 \\
\hline Finance and insurance & 2615.4 & 1.37 \\
\hline Market real estate and business services & 8393.4 & 2.43 \\
\hline Other private services & 1731.8 & 0.38 \\
\hline Government services & 10830.9 & 0.02 \\
\hline
\end{tabular}

\section{Conclusions and Policy Recommendations}

This study analyses the potential of manufacturing and services sectors in promoting economic growth and development in Namibia, in line with the country's long term development objective. Using impact analysis in order to identify and quantify the industries with the greatest linkages with the economy, and a CGE model to simulate the actual changes that could be expected to occur in the economy given exogenously induced changes in the key sectors to determine the economy-wide effect of exogenous changes in these industries, we have established that the key sectors of the economy are transport, communication, and finance and insurance. Beverages and other food processing have been shown to have the greatest impact in terms of the economy-wide effects of exogenous changes, with commercial cereal crops, commercial animal products, fishing, chemicals and rubber, non-metallic mineral products, fabricated metals and machinery, transport, finance and insurance, and market real estate and business services also having significant impact. Policies that promote investment in and and growth of these industries would thus have the greatest effect on the country's economy.

In order to unlock the potential of the manufacturing and services industries, promote economic growth and development, and enable the country to realise its long term development vision, it is necessary to increase investment in those industries with the greatest linkages. The greatest backward linkages were identified in the following manufacturing industries: meat processing, fish processing, grain milling, basic metals, and construction. Similar 
linkages for the tertiary industries were found in trade and repairs, hotels and restaurants, finance and insurance, and other private services. The greatest forward linkages were evident in the following manufacturing industries: paper and printing, chemicals and rubber, fabricated metals and machinery, and electricity. They were also found in the following tertiary industries: transport, communication, finance and insurance, and market real estate and business services. As part of the structural transformation process, there is a need for the country to design and implement policies targeting expansion in these industries as they present the greatest potential for promoting growth, creating jobs and generally moving the country towards the achievement of the stated long term development objective.

\section{Acknowledgements}

We would like to thank the editor and two anonymous referees for their helpful and constructive comments. The authors gratefully acknowledge funding from the United Nations Development Programme (UNDP), Namibia Country Office to conduct the study in 2011.

\section{References}

Abdelkhalek T., \& Dufour, J. (2006). Confidence regions for calibrated parameters in computable general equilibrium models. Annales d'Économie et de Statistique, 81. Retrieved from http://annales.ensae.fr/anciens/n81/vol81-01.pdf

Ahammad, H. (2002). A CGE approach to measuring the sectoral contribution to an economy: An application to Western Australian agriculture. RURDS, 14(3), 305-324.

Andreosso-O'Callaghan, B., \& Yue, G. (2004). Intersectoral linkages and key sectors in China, 1987-1997. Asian Economic Journal, 18(2), 165-183.

Bank of Namibia. (2008). Annual Report 2008. Windhoek, Namibia.

Bank of Namibia. (2009). Annual Report 2009. Windhoek, Namibia.

Blancas, A. (2006). Interinstitutional linkage analysis: A social accounting matrix multiplier approach for the Mexican economy. Economic Systems Research, 18(1), 29-59.

Chenery, H., \& Watanabe, E. T. (1958). International comparisons of the structure of production. Econometrica, 26, 487-521.

Cristobal, J. R. S., \& Biezma, M. V. (2006). The mining industry in the European Union: Analysis of inter-industry linkages using input-output analysis. Resources Policy, 31(1), 1-6.

Davis, H. C., \& Salkin, E. L. (1984). Alternative approaches to the estimation of economic impacts resulting from supply constraints. The Annals of Regional Science, 18, 25-34.

Devarajan, S., \& Go, D. S. (2002). The Impact of Computable General Equilibrium Models on Policy. Washington DC: International Food Policy Research Institute (IFPRI).

Dietzenbacher, E. (2002). Interregional multipliers: Looking backward, looking forward. Regional Studies, 36, 125-136.

Drejer, I. (2002). Input-output based measures of interindustry linkages revisited - a survey and discussion. The 14th International Conference on Input-Output Techniques. Université du Québec à Montréal, Canada, 10-15 October. Retrieved from http://www.iioa.at/pdf/14th\%20conf/Drejer_.pdf

Egilmez, G., Kucukvar, M., \& Tatari, O. (2013). Sustainability assessment of U.S. manufacturing sectors: An economic input output-based frontier approach. Journal of Cleaner Production, 53, 91-102.

Ghosh, A. (1958). Input-output approach to an allocative system. Economica, 25(1), 58-64.

Government of the Republic of Namibia. (1997). Namibia Labour Force Survey. Ministry of Labour and Social Welfare, Directorate of Labour Market Services.

Government of the Republic of Namibia. (2004). Namibia Labour Force Survey 2004. Ministry of Labour and Social Welfare, Directorate of Labour Market Services.

Government of the Republic of Namibia. (2008). Namibia Labour Force Survey 2008. Ministry of Labour and Social Welfare, Directorate of Labour Market Services.

Namibia Statistical Agency. (2014). retrieved on line from http://www.nsa.org.na/publications/

Government of the Republic of Namibia. (2004). Namibia Vision 2030: Policy Framework for Long-Term National Development. Windhoek. Namibia.

Kowalewski, J. (2013). Inter-industrial relations and sectoral employment development in German regions. Journal of Economics and Statistics, 233(4), 486-504. 
Hirschman, A. O. (1958). The Strategy of Economic Development. New Haven: Yale University Press.

Lange, G. M., \& Schade, K. (2008). A social accounting matrix for Namibia, 2004: A tool for analyzing economic growth, income distribution and poverty. NEPRU Working Paper 112. Namibian Economic Policy Research Unit, Windhoek.

Leontief, W. (1936). Quantitative input and output relations in the economic systems of the United States. Review of Economics and Statistics, 18(3), 105-125.

Oosterhaven, J. (1988). On the plausibility of the supply-driven input-output model. Journal of Regional Science, 28, 203-217.

Oosterhaven, J. (1996). Leontief versus Ghoshian price and quantity models. Southern Economic Journal, 62, $750-759$.

Rasmussen, P. N. (1956). Studies in Inter-sectoral Relations, North-Holland, Amsterdam.

Salami, H., Sadat, Barikani, H., \& Noori Naeini, M. S. (2012). Can agriculture be considered a key sector for economic development in an oil producing country? The case of Iran. Journal of Agricultural Science and Technology, 14, $1-10$.

United Nations Development Programme (UNDP). (2014). Human Development Report 2014: Sustaining Human Progress: Reducing Vulnerabilities and Building Resilience. New York, NY: UNDP.

Yeldan, A. E. (1986). A computable general equilibrium model for development policy analysis, Economic Development Centre', Bulletin Number 86-1.

This work is licensed under a Creative Commons Attribution 3.0 License. 